\title{
Molecular characterization of antimicrobial resistance and virulence genes of Escherichia coli isolates from bovine mastitis
}

\author{
Zuhair Bani Ismail(1D and Sameeh M. Abutarbush (i) \\ Department of Veterinary Clinical Sciences, Faculty of Veterinary Medicine, Jordan University of Science and Technology, \\ Irbid, Jordan. \\ Corresponding author: Zuhair Bani Ismail, e-mail: zuhair72@just.edu.jo \\ Co-author: SMA: smabutarbush@just.edu.jo \\ Received: 11-02-2020, Accepted: 22-06-2020, Published online: 14-08-2020
}

doi: www.doi.org/10.14202/vetworld.2020.1588-1593 How to cite this article: Ismail ZB, Abutarbush SM (2020) Molecular characterization of antimicrobial resistance and virulence genes of Escherichia coli isolates from bovine mastitis, Veterinary World, 13(8): 1588-1593.

\begin{abstract}
Background and Aim: Mastitis is a common and economically important disease in dairy cattle. It remains one of the most common reasons for the extensive use of antimicrobials in dairy farms leading to the emergence of antimicrobial-resistant pathogens. The aim of this study was to determine the patterns of antimicrobial resistance of Escherichia coli isolates from bovine mastitis and to identify prominent antimicrobial resistance and virulence genes among isolated strains.
\end{abstract}

Materials and Methods: Antimicrobial susceptibility testing against six antibiotic groups, including tetracyclines, aminoglycosides, beta-lactams, macrolides, sulfonamides, and fluoroquinolones was performed using the disk diffusion method. PCR was performed on resistant isolates to detect resistance and virulence genes using commercially available primers.

Results: Out of 216 milk samples cultured, 14 samples yielded E. coli isolates. All isolates (100\%) were resistant to ampicillin, amoxicillin, procaine penicillin, streptomycin, oxytetracycline, and sulfamethoxazole-trimethoprim. Only one isolate (7\%) was sensitive to gentamicin, and all isolates (100\%) were sensitive to enrofloxacin and ciprofloxacin. All isolates carried at least one resistance gene against one or more of the major antibiotic groups. All isolates carried the ere $A$, tet $G$, tetE, and tetB genes, followed by tetA (93\%), ampC (86\%), strA (86\%), sull (78\%), tetD (71\%), tetC (57\%), aadA $(57 \%)$, and $\operatorname{str} B(36 \%)$. The lowest percentage of isolates carried blal $(17 \%)$ and bla2 (12\%) genes, and none of the isolates carried the qnrA gene. Most of the isolates (93\%) carried the Shiga toxin 1 virulence gene, followed by complement resistance protein $(79 \%)$, intimin (64\%), Shiga toxin $2(36 \%)$, cytotoxic necrotizing factor $(35 \%)$, aerotaxis receptor $(21 \%)$, and type 1 fimbriae (15\%).

Conclusion: Results of this study indicate that the high percentages of $E$. coli isolate from bovine mastitis are resistant to two or more of the major antibiotic groups, irrespective of the presence or absence of relevant resistance or virulence genes.

Keywords: antimicrobial resistance, dairy cows, environmental mastitis pathogens, Escherichia coli.

\section{Introduction}

Mastitis is one of the most economically important diseases of dairy cattle [1,2]. Economic losses are due to discarded milk, reduced milk production, costs of veterinary services and medications, and death or early culling of affected cows [1,2]. Mastitis is also a cause of serious concern to the well-being of cows and is considered a threat to public health [1,2]. Escherichia coli is considered one of the most important causes of clinical and subclinical mastitis in dairy cows [3]. Clinical signs of $E$. coli mastitis range from severe peracute disease to subclinical and chronic infection, depending on the virulence of the invading strain and immune responses of affected cows [3].

Copyright: Ismail and Abutarbush. Open Access. This article is distributed under the terms of the Creative Commons Attribution 4.0 International License (http://creativecommons.org/licenses/ by/4.0/), which permits unrestricted use, distribution, and reproduction in any medium, provided you give appropriate credit to the original author(s) and the source, provide a link to the Creative Commons license, and indicate if changes were made. The Creative Commons Public Domain Dedication waiver (http:// creativecommons.org/publicdomain/zero/1.0/) applies to the data made available in this article, unless otherwise stated.
E. coli is a rod-shaped, flagellated, facultative anaerobic, non-sporulating, and Gram-negative bacterium of the Enterobacteriaceae family. Several E. coli isolates from raw milk and dairy products are known to cause severe foodborne illnesses in humans, including hemolytic uremic syndrome, thrombotic thrombocytopenic purpura, hemorrhagic colitis, and bloody diarrhea [4-11]. Among many virulence genes identified in E. coli isolated from bovine clinical mastitis, Shiga toxins (Stxl and Stx2), and eae (intimin) remain the most significant genes with great public health concern $[5,6]$. The emergence of the antimicrobial-resistant $E$. coli strains isolated from human clinical samples, and dairy cow mastitis is increasing at an alarming pace causing worldwide public health concerns $[12,13]$. There is strong scientific evidence that connects the development of resistance in E. coli strains isolated from human clinical samples and those isolated from animals [14-18].

The aim of this study was to characterize the antimicrobial resistance patterns and to identify different resistance and virulence genes in E. coli strain isolated from bovine acute mastitis in Jordan. 


\section{Materials and Methods}

\section{Ethical approval and informed consent}

This study was carried out after approval by the institutional animal care, and use committee of Jordan University of Science and Technology was obtained (Grant Number 399-2019). Appropriate farm owner consents were obtained in written forms before the samples were obtained from affected cows.

\section{Sample collection}

A total of 216 quarter milk samples were collected from 161 dairy cows with acute clinical mastitis from June to August 2019. Cows belonged to 10 farms located in the North Eastern region of Jordan. Affected cows were subjected to a complete physical examination, including heart rate, respiration rate, rectal temperature, and rumen motility (Data are not presented here). Examination of the mammary glands was carried out and included palpation of the udder and teats (to detect heat, pain, or swelling), followed by inspection of milk secretion (for color and consistency). Once the diagnosis of clinical mastitis was confirmed, approximately $100 \mathrm{~mL}$ of milk samples were collected from affected quarters using an aseptic technique, according to the previously published procedures [19]. The samples were transferred to the laboratory at $4^{\circ} \mathrm{C}$ within 3-4 h after collection.

\section{Bacterial culture and identification}

Approximately $0.1 \mathrm{~mL}$ of raw milk were spread evenly on 5\% sheep's blood agar, MacConkey, and EMB agar (Merck, Germany) plates and incubated at $37^{\circ} \mathrm{C}$ for $24 \mathrm{~h}$. Suspected $E$. coli colonies were initially identified phenotypically based on the formation of green metallic sheen on EMB. Suspected E. coli colonies were then confirmed biochemically using Gram's stain, catalase, oxidase, triple sugar iron agar, and IMViC tests [7]. Further confirmation of E. coli was carried out using PCR to detect the $16 \mathrm{~S} r R N A$ gene [20].

\section{Antimicrobial sensitivity testing}

The antimicrobial sensitivity test was performed using the Kirby-Bauer disk diffusion method on Mueller-Hinton agar (Sigma-Aldrich, USA), according to the previously published procedures [21]. The antimicrobial agents tested were amoxicillin (10 mg), ampicillin (10 mg), procaine penicillin G (10 IU), streptomycin (10 $\mathrm{mg})$, gentamicin $(10 \mathrm{mg})$, erythromycin (15 mg), ciprofloxacin (5 mg), oxytetracycline (30 mg), trimethoprim/sulfamethoxazole (25 mg), and enrofloxacin (5 mg). E. coli strain American Type Culture Collection (ATCC) 25922 was used as a reference strain. Plates were incubated at $37^{\circ} \mathrm{C}$ for $24 \mathrm{~h}$, and the sensitivity patterns were read and reported according to the diameter of the inhibition zone as sensitive, intermediate, or resistant [21].

\section{DNA extraction and PCR amplification}

DNA extraction was performed on all E. coli isolates that were phenotypically resistant on the disk diffusion sensitivity test. Bacterial DNA was extracted using Qiagen DNeasy Blood and Tissue Kit (Life Technologies, USA), according to the manufacturer's instructions. The quality and quantity of isolated DNA were verified using NanoDrop 2000c (Thermo Fischer Scientific, USA) and stored at $-20^{\circ} \mathrm{C}$ until further use.

PCR analysis was performed to detect 15 resistance and seven virulence genes using previously published primers (Tables-1 and 2) [2,22]. Each PCR reaction was performed in a volume of $25 \mu \mathrm{L}$ that contained the following substrates: $1.5 \mu \mathrm{L} \mathrm{MgCl}_{2}, 2.5 \mu \mathrm{L}$ PCR buffer, $200 \mu \mathrm{M}$ dNTPs, $1 \mu \mathrm{M}$ each primer, $5 \mathrm{U}$ of Taq DNA polymerase, and $1 \mu \mathrm{L}(50-200 \mathrm{ng} / \mu \mathrm{L})$ of test DNA. The PCR machine was set using the following program: Denaturation for $5 \mathrm{~min}$ at $95^{\circ} \mathrm{C}$, then 30 cycles of $1 \mathrm{~min}$ at $94^{\circ} \mathrm{C}, 60 \mathrm{~s}$ at $52-58^{\circ} \mathrm{C}$, and $1 \mathrm{~min}$ at $72^{\circ} \mathrm{C}$. The final extension step was set to $10 \mathrm{~min}$ at $72^{\circ} \mathrm{C}$. The resultant PCR products were viewed using $1.5 \%$ agarose gel using electrophoresis.

\section{Results}

Out of 216 milk samples cultured, 14 isolates were positively identified as E. coli. All isolates $(100 \%)$ were resistant to ampicillin, amoxicillin, procaine penicillin, streptomycin, oxytetracycline, and sulfamethoxazole-trimethoprim. Only one isolate $(7.14 \%)$ was sensitive to gentamicin and all isolates $(100 \%)$ were sensitive to enrofloxacin and ciprofloxacin (Table-3).

All isolates carried at least one resistance gene against one or more of the major antibiotic groups under study (Figure-1). One hundred percent of the isolates carried the ere $A$, tet $G$, tet $E$, and tet $B$ genes, followed by tetA $(93 \%), \operatorname{ampC}(86 \%), \operatorname{str} A(86 \%)$, sull (78\%), tetD (71\%), tetC (57\%), aadA (57\%), and strB $(36 \%)$. The lowest percentage of isolates carried bla1 (17\%) and bla2 (12\%) genes and none of the isolates carried the $q n r A$ gene.

The results of the PCR detection of various virulence genes are presented in Figure-2. Most of the isolates $(93 \%)$ carried the Shiga toxin 1 virulence gene, followed by complement resistance protein $(79 \%)$, intimin $(64 \%)$, Shiga toxin $2(36 \%)$, cytotoxic

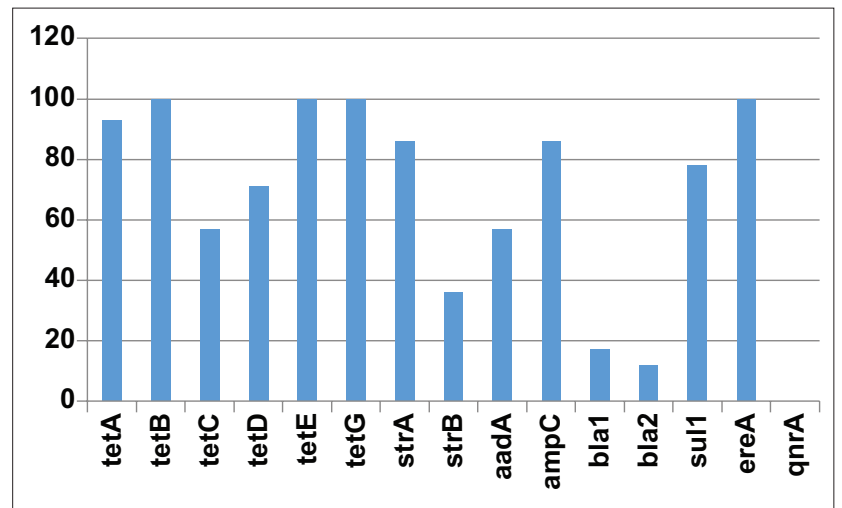

Figure-1: Frequency (\%) of $E$. coli isolates from bovine mastitis carrying resistance genes against major antibiotic groups. 
Table-1: Oligonucleotide primers used to detect antimicrobial resistance genes.

\begin{tabular}{|c|c|c|c|}
\hline Antibiotic group & Target genes & Primer sequence & Size (bp) \\
\hline \multirow[t]{11}{*}{ Tetracyclines } & tet $A$ & $\begin{array}{l}\text { F: GGCCTCAATTTCCTGACG } \\
\text { R: AAGCAGGATGTAGCCTGTGC }\end{array}$ & 372 \\
\hline & tet $B$ & F: GAGACGCAATCGAATTCGG & 228 \\
\hline & & R: TITAGTGGCTATTCTTCCTGCC & \\
\hline & tetC & F: TGCTCAACGGCCTCAACC & 397 \\
\hline & & R: AGCAAGACGTAGCCCAGCG & \\
\hline & tetD & F: GGATATCTCACCGCATCTGC & 436 \\
\hline & & R: CATCCATCCGGAAGTGATAGC & \\
\hline & tetE & F: TCCATACGCGAGATGATCTCC & 442 \\
\hline & & R: CGATTACAGCTGTCAGGTGGG & \\
\hline & tetG & F: CAGCTTTCGGATTCTTACGG & 844 \\
\hline & & R: GATTGGTGAGGCTCGTTAGC & \\
\hline \multirow[t]{6}{*}{ Aminoglycosides } & strA & F: CTTGGTGATAACGGCAATTC & 548 \\
\hline & & R: CCAATCGCAGATAGAAGGC & \\
\hline & strB & F: ATCGTCAAGGGATTGAAACC & 509 \\
\hline & & R: GGATCGTAGAACATATTGGC & \\
\hline & $\operatorname{aad} A$ & F: GTGGATGGCGGCCTGAAGCC & 525 \\
\hline & & R: AATGCCCAGTCGGCAGCG & \\
\hline \multirow[t]{6}{*}{ Beta-lactams } & $a m p C$ & F: TTCTATCAAMACTGGCARCC & 1048 \\
\hline & & R: CCYTITTATGTACCCAYGA & \\
\hline & bla1 & F: TCGCCTGTGTATTATCTCCC & 768 \\
\hline & & R: CGCAGATAAATCACCACAATG & \\
\hline & bla2 & F: TGGCCAGAACTGACAGGCAAA & 462 \\
\hline & & R: TTCTCCTGAACGTGGCTGGC & \\
\hline \multirow[t]{2}{*}{ Macrolides } & ereA & F: GCCGGTGCTCATGAACTTGAG & 419 \\
\hline & & R: CGACTCTATTCGATCAGAGGC & \\
\hline \multirow[t]{2}{*}{ Sulfonamides } & sul1 & F: TTCGGCATTCTGAATCTCAC & 822 \\
\hline & & R: ATGATCTAACCCTCGGTCTC & \\
\hline \multirow[t]{2}{*}{ Fluoroquinolones } & qnrA & F: ATTTCTCACGCCAGGATTTG & 516 \\
\hline & & R: GATCGGCAAAGGTTAGGTCA & \\
\hline
\end{tabular}

Table-2: Oligonucleotide primers used to detect virulence genes.

\begin{tabular}{|c|c|c|c|}
\hline Target genes & Target protein & Primer sequence & Size (bp) \\
\hline eaeA & Intimin & $\begin{array}{l}\text { F: ATATCCGTITIAATGGCTATCT } \\
\text { R: AATCTTCTGCGTACTGTGTTCA }\end{array}$ & 425 \\
\hline aer & Aerotaxis receptor & $\begin{array}{l}\text { F: TACCGGATTGTCATATGCAGACCGT } \\
\text { R: AATATCTTCCTCCAGTCCGGAGAAG }\end{array}$ & 602 \\
\hline trat & Complement resistance protein & $\begin{array}{l}\text { F: GATGGCTGAACCGTGGTTATGCACA } \\
\text { R: CGGGTCTGGTATTATGC }\end{array}$ & 307 \\
\hline stx 1 & Shiga toxins 1 & $\begin{array}{l}\text { F: ATAAATCGCCATTCGTTGACTACAG } \\
\text { R: AACGCCCACTGAGATCATCGGCACT }\end{array}$ & 180 \\
\hline stx2 & Shiga toxins 2 & $\begin{array}{l}\text { F: GTCTGAAACTGCTCCTCGCCAGTTA } \\
\text { R: TCGCCAGTTATCTGACATTCTG }\end{array}$ & 255 \\
\hline $\mathrm{fimH}$ & Type 1 fimbriae & $\begin{array}{l}\text { F: TGCAGAACGGATAAGCCGTGG } \\
\text { R:GCAGTCACCTGCCCTCCGGTA }\end{array}$ & 508 \\
\hline Cnf & Cytotoxic necrotizing factor & $\begin{array}{l}\text { F: CTGGACTCGAGGTGGTGG } \\
\text { R: CTCCTGTCAACCACAGCC }\end{array}$ & 533 \\
\hline
\end{tabular}

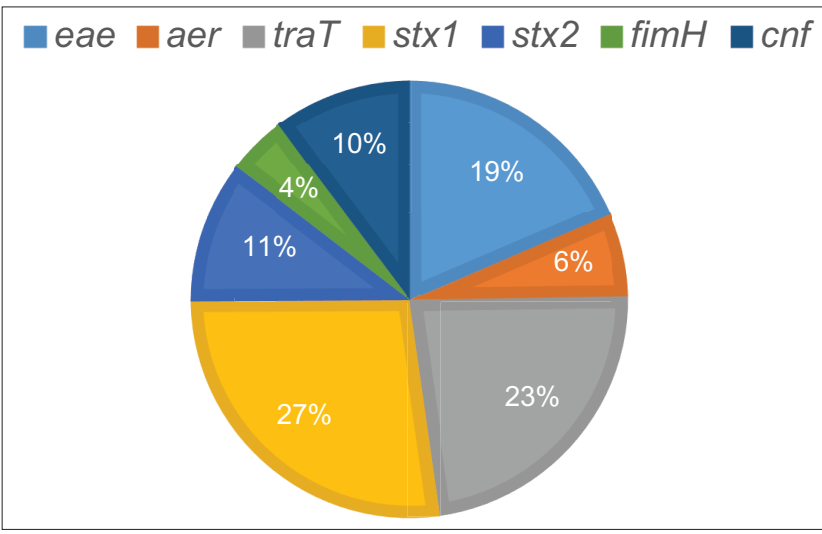

Figure-2: Frequency (\%) of $E$. coli isolates from bovine mastitis carrying different virulence genes. necrotizing factor $(35 \%)$, aerotaxis receptor $(21 \%)$, and type 1 fimbriae (15\%).

\section{Discussion}

In this study, $100 \%$ of isolated E. coli strains from mastitis in dairy cows were resistant to seven out of ten different antibiotic agents belonging to six different major groups of antimicrobials. These findings are alarming and indicate a possible association between various antimicrobial resistance genes causing widespread resistance among bacterial strains isolated from dairy cows. It has been suggested that selective use of certain antibiotics in animal production has led to the emergence and dissemination 
Table-3: Numbers and percentages (\%) of sensitive, intermediate, and resistant Escherichia coli strains isolated from bovine mastitis against common antibiotic agents $(n=14)$.

\begin{tabular}{lccc}
\hline $\begin{array}{l}\text { Antibiotic } \\
\text { agents }\end{array}$ & Sensitive & Intermediate & Resistant \\
\hline $\begin{array}{l}\text { Gentamicin } \\
(10 \mathrm{mg})\end{array}$ & $1(7.14 \%)$ & $3(21.43)$ & $10(71.43)$ \\
$\begin{array}{l}\text { Enrofloxacin } \\
(5 \mathrm{mg})\end{array}$ & $14(100)$ & 00 & 00 \\
$\begin{array}{l}\text { Ciprofloxacin } \\
(5 \mathrm{mg})\end{array}$ & $14(100)$ & 00 & 00 \\
$\begin{array}{l}\text { Ampicillin } \\
(10 \mathrm{mg})\end{array}$ & 00 & 00 & $14(100)$ \\
$\begin{array}{l}\text { Amoxicillin } \\
(10 \mathrm{mg})\end{array}$ & 00 & 00 & $14(100)$ \\
$\begin{array}{l}\text { Procaine } \\
\text { penicillin (10 IU) }\end{array}$ & 00 & 00 & $14(100)$ \\
$\begin{array}{l}\text { Streptomycin } \\
(10 \mathrm{mg})\end{array}$ & 00 & 00 & $14(100)$ \\
$\begin{array}{l}\text { Oxytetracycline } \\
(30 \mathrm{mg})\end{array}$ & 00 & 00 & $14(100)$ \\
$\begin{array}{l}\text { Sulfamethoxazole- } \\
\text { Trimethoprim } \\
(25 \mathrm{mg})\end{array}$ & 00 & 00 & $14(100)$ \\
\hline
\end{tabular}

of bacterial strains carrying resistance genes against multiple antibacterial agents [23]. Therefore, accurate diagnosis, judicious use of antimicrobials, and the use of a most sensitive antimicrobial agent to treat infectious diseases must be practiced in agricultural operations to limit the emergence and spread of multidrug-resistant pathogens among animals as well as humans.

The antibiotic resistance profile of $E$. coli presented in this study indicates that all isolates carried most of the genes responsible for resistance against major antimicrobial groups. Multidrug-resistant $E$. coli has been isolated from both animal and human clinical samples with an increasing rate [24]. The different levels of the resistance of $E$. coli have been reported against common antimicrobial agents, including penicillin, amoxicillin, ampicillin, streptomycin, tylosin, oxytetracycline, erythromycin, and neomycin [25]. Among various studies, differences in assay sensitivity, laboratory culture procedures and conditions, bacterial identification procedures, sampling protocols, and sample sources, and the previous exposure to different antimicrobials all may lead to variation in sensitivity patterns.

In this study, all isolates carried the ere $A$, tet $G$, tet $E$, and tet $B$ genes, followed by tet $A(93 \%)$, amp $C$ $(86 \%)$, strA $(86 \%)$, sull $(78 \%)$, tetD $(71 \%)$, tetC $(57 \%)$, aadA $(57 \%)$, and strB $(36 \%)$. The lowest percentage of isolates carried bla1 (17\%) and bla2 (12\%) genes, and none of the isolates carried the qnr $A$ gene. These results are similar to previously reported findings, in which various resistance gene combinations were reported in isolated E. coli. In one study, 78\% of isolated $E$. coli strains from mastitis in cows were resistant to more than one antibiotic and carried multiple resistance genes, including tet $A$, tet $B$, ampC
tetD, tetE, and tet $G$ [2]. However, unlike our results, none of the $E$. coli in that study carried the blal and only a small percentage carried the bla2 genes [2]. In general, it has been suggested that resistant bacterial strains do not necessarily carry the genes responsible for the conferred resistance, which may suggest the presence of other mechanisms of resistance in such isolates [26].

In this study, all isolates were susceptible to both antibiotic agents belonging to fluoroquinolones. These results are in line with the previous findings, in which all $E$. coli isolates from bovine clinical mastitis were sensitive to enrofloxacin [25]. The resistance against quinolones has been described to be acquired either by mutations, downregulation, or modification of the efflux pumps activity or by the acquisition of plasmid resistance genes ( $q n r$ proteins) [27]. The plasmid-acquired quinolone resistance, however, has been described to lead to a low level of resistance against fluoroquinolones [28]. The fact that none of the isolates carried the qnr gene and all isolates were phenotypically sensitive indicates that the bacteria lack the ability to effectively develop resistance against this group of antimicrobials.

The virulence gene profile in $E$. coli isolates in this study was variable. Most of the isolates were found to carry the Shiga toxin 1, complement resistance protein, intimin, Shiga toxin 2, and cytotoxic necrotizing factor. Similar results were reported previously, in which most of the $E$. coli strains isolated from mastitic milk were found to carry the genes for complement resistance protein (traT), Shiga toxin 1 (stx1), Shiga toxin 2 (stx2), and intimin (eaeA) [2]. Other studies, however, have not detected stx 1 and stx 2 genes in any of the E. coli isolates [29]. It is worth to note here that a direct relationship has also been found between the presence of intimin gene and the ability of $E$. coli to cause serious disease in human beings [25]. Another intriguing finding in this study is the detection of both stx 1 and stx 2 genes in most of isolates. It is well known that these genes are present in Shiga toxin-producing E. coli (STEC) and are considered the primary virulence genes responsible for serious public health threats [30]. In Jordan, high rates of MDR pathogenic $E$. coli strains have been isolated from patients suffering from urinary tract infections [31]. These uropathogenic E. coli strains were mostly positive for ST131 and blaC$T X-M$ genes [31]. In another study, high rates of MDR pathogenic E. coli strains, including extended-spectrum beta-lactamase (ESBL) and carbapenemase-producing strains were recovered from different water sources in Jordan [32]. Therefore, the results of this study are in congruence with the previous findings in Jordan, indicating a continuing urgency for stricter regulations of antimicrobial use in dairy animals [33]. Indeed, the previous results obtained in one large study involving 43 dairy herds from Northwestern Jordan concluded that antimicrobials are frequently 
misused in dairies leading to the emergence of MDR strains of commensal E. coli [33].

\section{Conclusion}

The results of this study indicate that the high percentage of $E$. coli isolates from bovine acute mastitis is resistant to two or more antibiotic groups, irrespective of the presence or absence of relevant resistance and virulence genes. These results raise a red flag on the overzealous use of antimicrobials in the dairy sector and provide a better understanding of pathogen dynamics in the field, which ultimately will improve the treatment outcome of infectious diseases.

\section{Authors' Contributions}

ZBI designed the study, collected samples, performed data analysis, wrote the manuscript and managed correspondence. SMA performed data analysis and interpretation, edited the manuscript. Both authors read and approved the final manuscript.

\section{Acknowledgments}

The authors would like to thank the Deanship of Research at Jordan University of Science and Technology for funding this project (Grant Number 399-2019).

\section{Competing Interests} interests.

The authors declare that they have no competing

\section{Publisher's Note}

Veterinary World remains neutral with regard to jurisdictional claims in published institutional affiliation.

\section{References}

1. Hogeveen, H., Huijps, K. and Lam, T.J.G. (2011) Economic aspects of mastitis: New developments. N. Z. Vet. J., 59(1): 16-23.

2. Ashraf, A., Imran, M. and Chang, Y. (2018) Antimicrobial resistance of Escherichia coli isolates from mastitic milk and its possible relationship with resistance and virulence genes. Pak. J. Zool., 50(4): 1435-1441.

3. Burvenich, C., Van Merris, V., Mehrzad, J., Diez-Fraile, A. and Duchateau, L. (2003) Severity of E. coli mastitis is mainly determined by cow factors. Vet. Res., 34(5): 521-564.

4. Farshad, S., Ranijbar, R., Japoni, A., Hosseini, M., Anvarinejad, M. and Mohammadzadegan, R. (2012) Microbial susceptibility, virulence factors, and plasmid profiles of uropathogenic Escherichia coli strains isolated from children in Jahrom, Iran. Arch. Iran Med., 15(5): 312-316.

5. Momtaz, H., Farzan, R., Rahimi, E., Dehkordi, F.S. and Souod, N. (2012) Molecular characterization of Shiga toxin-producing Escherichia coli isolated from ruminant and donkey raw milk samples and traditional dairy products in Iran. Sci. World J., Volume 2012, Article ID 231342, 13 pages.

6. Momtaz, H., Dehkordi, F.S., Rahimi, E., Ezadi, H. and Arab, R. (2013a) Incidence of Shiga toxin-producing Escherichia coli serogroups in ruminant's meat. Meat Sci., 95(2): 381-388.

7. Momtaz, H., Dehkordi, F.S., Rahimi, E. and Asgarifar, A. (2013b) Detection of Escherichia coli, Salmonella species, and Vibrio cholerae in tap water and bottled drinking water in Isfahan, Iran. BMC Public Health, 13(1): 556.

8. Dehkordi, F.S., Yazdani, F., Mozafari, J. and Valizadeh, Y. (2014) Virulence factors, serogroups and antimicrobial resistance properties of Escherichia coli strains in fermented dairy products. BMC Res. Notes, 7: 217.

9. Bai, X., Zhang, W., Tang, X., Xin, Y., Xu, Y., Sun, H., Luo, X., Pu, J., Xu, J. and Xiong, Y. (2016) Shiga toxin-producing Escherichia coli in plateau pika (Ochotona curzoniae) on the Qinghai-Tibetan plateau, China. Front. Microbiol., 7: 375.

10. Dhaka, P., Vijay, D., Vergis, J., Negi, M., Kumar, M., Mohan, V., Doijad, S., Poharkar, K.V., Malik, S.S. and Barbuddhe, S.B. (2016) Genetic diversity and antibiogram profile of diarrhoeagenic Escherichia coli pathotypes isolated from human, animal, foods and associated environmental sources. Infect. Ecol. Epidemiol., 6: 31055.

11. Wang, J., Stanford, K., McAllister, T.A., Johnson, R.P., Chen, J., Hou, H., Zhang, G. and Niu, Y.D. (2016) Biofilm formation, virulence gene profiles, and antimicrobial resistance of nine serogroups of non-O157 Shiga toxin-producing Escherichia coli. Foodborne Pathog. Dis., 13(6): 316-324.

12. Kahlmeter, G. and Poulsen, H.O. (2012) Antimicrobial susceptibility of Escherichia coli from community-acquired urinary tract infections in Europe: The ECO-SENS study revisited. Int. J. Antimicrob. Agents, 39(1): 45-51.

13. Copur-Cicek, A., Ozgumus, O.B., Saral, A. and Sandalli, C. (2014) Antimicrobial resistance patterns and integron carriage of Escherichia coli isolates causing community-acquired infections in Turkey. Ann. Lab. Med., 34(2): 139-144.

14. Altalhi, A.D., Gherbawy, Y.A. and Hassan, S.A. (2010) Antibiotic resistance in Escherichia coli isolated from retail raw chicken meat in Taif, Saudi Arabia. Foodborne Pathog. Dis., 7(3): 281-285.

15. Lei, T., Tian, W., He, L., Huang, X.H., Sun, Y.X., Deng, Y.T., Sun, Y., Lv, D.H., Wu, C.M. and Huang, L.Z. (2010) Antimicrobial resistance in Escherichia coli isolates from food animals, animal food products and companion animals in China. Vet. Microbiol., 146(1): 85-89.

16. Cantas, L., Shah, S.Q.A., Cavaco, L.M., Manaia, C.M., Walsh, F., Popowska, M., Garelick, H., Bürgmann, H. and Sørum, H. (2013) A brief multi-disciplinary review on antimicrobial resistance in medicine and its linkage to the global environmental microbiota. Front. Microbiol., 4: 96.

17. Rasheed, M.U., Thajuddin, N., Ahamed, P., Teklemariam, Z. and Jamil, K. (2014) Antimicrobial drug resistance in strains of Escherichia coli isolated from food sources. Rev. Inst. Med. Trop., 56(4): 341-346.

18. Walther, B., Tedin, K. and Lübke-Becker, A. (2017) Multidrug-resistant opportunistic pathogens challenging veterinary infection control. Vet. Microbiol., 200: 71-78.

19. Metzger, S.A., Hernandez, L., Skarlupka, J.H., Suen, G., Walker, T.M. and Ruegg, P.L. (2018) Influence of sampling technique and bedding type on the milk microbiota: Results of a pilot study. J. Dairy Sci., 101(7): 6346-6356.

20. Suardana, I.W. (2014) Analysis of nucleotide sequences of the 16S rRNA gene of novel Escherichia coli strains isolated from feces of human and Bali cattle. J. Nucleic Acids, 2014: Article ID 475754.

21. Patel, J.B., Cockerill, F., Bradford, P.A. and Eliopoulos, G.M. (2015) Performance Standards for Antimicrobial Susceptibility Testing. $25^{\text {th }}$ ed. Informational Supplement, Clinical and Laboratory Standards Institute, Wayne, PA.

22. Fernandes, J.B.C., Zanardo, L.G., Galvão, N.N., Carvalho, I.A., Nero, L.A. and Moreira, M.A.S. (2011) Escherichia coli from clinical mastitis: Serotypes and virulence factors. J. Vet. Diagn. Investig., 23(6): 1146-1152.

23. Economou, V. and Gousia, P. (2015) Agriculture and food animals as a source of antimicrobial-resistant bacteria. Infect. Drug Resist., 8: 49-61.

24. Srinivasan, V., Gillespie, B.E., Lewis, M.J., Nguyen, L.T., Headrick, S.I., Schukken, Y.H. and Oliver, S.P. (2007) 
Phenotypic and genotypic antimicrobial resistance patterns of Escherichia coli isolated from dairy cows with mastitis. Vet. Microbiol., 124(3): 319-328.

25. Tavakoli, M. and Pourtaghi, H. (2017) Molecular detection of virulence genes and multidrug resistance patterns in Escherichia coli (STEC) in clinical bovine mastitis: Alborz Province, Iran. Iran J. Vet. Res., 18(3): 208-211.

26. Davies, J. and Davies, D. (2010) Origins and evolution of antibiotic resistance. Microbiol. Mol. Biol. Rev., 74(3): 417-433.

27. Jacoby, G.A. (2005) Mechanisms of resistance to quinolones. Clin. Infect. Dis., 41(Suppl 2): S120-S126.

28. Strahilevitz, J., Jacoby, G.A., Hooper, D.C. and Robicsek, A. (2009) Plasmid-mediated quinolone resistance: A multifaceted threat. Clin. Microbiol. Rev., 22(4): 664-689.

29. Dong, H., Zhang, H., Li, K., Mehmood, K., Rehman, M.U., Nabi, F., Wang, Y., Chang, Z., Wu, Q. and Li, J. (2017) Prevalence and potential risk factors for Escherichia coli isolated from Tibetan piglets with white score diarrhea.
Pak. J. Zool., 50(1): 57-63.

30. Montso, P.K., Mlambo, V. and Ateba, C.N. (2019) The first isolation and molecular characterization of shiga toxin-producing virulent multi-drug resistant atypical enteropathogenic E. coli O177 serogroup from South African cattle. Front. Cell. Infect. Microbiol., 9: 333.

31. Nairoukh, Y.R., Mahafzah, A.M., Irshaid, A. and Shehabi, A.A. (2018) Molecular characterization of multidrug-resistant uropathogenic $E$. coli isolates from Jordanian patients. Open Microbiol. J., 12: 1-7.

32. Swedan, S. and Abu Alrub, H. (2019) Antimicrobial resistance, virulence factors, and pathotypes of Escherichia coli isolated from drinking water sources in Jordan. Pathogens, 8(2): 86.

33. Obaidat, M.M., Salman, A.E.B., Davis, M.A. and Roess, A.A. (2018) Major diseases, extensive misuse, and high antimicrobial resistance of Escherichia coli in large and small-scale dairy cattle farms in Jordan. J. Dairy Sci., 1010(3): 2324-2334.

$* * * * * * * *$ 